https://helda.helsinki.fi

\title{
The Anthropocene exit : Reconciling discursive tensions on the new geological epoch
}

\section{Heikkurinen, Pasi}

2019-10

Heikkurinen , P , Ruuska , T , Wilen , K \& Ulvila , M 2019 , ' The Anthropocene exit :

Reconciling discursive tensions on the new geological epoch ', Ecological Economics, vol.

164,106369 . https://doi.org/10.1016/j.ecolecon.2019.106369

http://hdl.handle.net/10138/332176

https://doi.org/10.1016/j.ecolecon.2019.106369

cc_by_nc_nd

acceptedVersion

Downloaded from Helda, University of Helsinki institutional repository.

This is an electronic reprint of the original article.

This reprint may differ from the original in pagination and typographic detail.

Please cite the original version. 
(C) The Authors

Reference: Heikkurinen, P., Ruuska, T., Wilén, K., Ulvila, M. (2019). The Anthropocene Exit: Reconciling Discursive Tensions on the New Geological Epoch. Ecological Economics, 1-33, in print.

\title{
The Anthropocene Exit: Reconciling Discursive Tensions on the New Geological Epoch
}

\author{
Pasi Heikkurinen a,b, ${ }^{\text {, }}$, Toni Ruuska ${ }^{\text {a }}$, Kristoffer Wilén ${ }^{c}$, Marko Ulvila ${ }^{\text {d }}$ \\ ${ }^{a}$ University of Helsinki, Department of Economics and Management \\ ${ }^{\mathrm{b}}$ University of Leeds, Sustainability Research Institute \\ ${ }^{c}$ Hanken School of Economics, Department of Marketing \\ ${ }^{\mathrm{d}}$ Siemenpuu Foundation \\ *Corresponding author's email: pasi.heikkurinen@helsinki.fi
}

\begin{abstract}
This article aims to reconcile tensions around 'the Anthropocene' by reviewing and integrating the discourses on the new geological epoch. It is argued that the Anthropocene discourses based on natural and social sciences are complementary. The anthropogenic epoch detrimental to the Earth's biodiversity, however, does not reduce to any discourse. Instead of calling to reject discourses that do not accept this limitation of language or alternatively do not show sensitivity to contextual matters, the article demonstrates how different Anthropocene discourses can be combined. The study concludes that in order to exit the epoch, anthropocentric discourses on the Anthropocene remain ineffective unless complemented by non-anthropocentric discourses.
\end{abstract}

Keywords: Anthropocene; anthropocentric; anthropogenic; discourse; growth; productivism

\section{Introduction}


The consequences of human dominance and exploitation of ecosystems have been recognised for decades (e.g., McKibben, 1989; Meadows et al., 1972; 2005). The recent debate on the Anthropocene illuminates this imbalance in the biosphere, the global sum of ecosystems. The scientific evidence on anthropogenic influence is more robust and alarming than ever, suggesting that humans have become a geological force (see Crutzen and Stoermer, 2000). While ecological degradation has occurred with undesired consequences for numerous past civilisations throughout recorded human history (Hornborg, 2011; Tainter, 2015), 'the Anthropocene' conveys a different message. Never before has the scale of the human-induced destruction affected the living conditions of almost all earthbound beings (Steffen et al., 2015b; Heikkurinen, 2017). Human power and weight in the biosphere are no longer fearmongering about the end of the world, but an empirical fact. In the present ecological crisis, ecosystems are being pushed outside safe boundaries with catastrophic consequences for the anthropos, as well as for the non-human world (Barnosky et al., 2012; Steffen et al., 2015a).

The natural scientific discourses on the Anthropocene have importantly stressed the causes and consequences of anthropogenic changes in ecosystems and the biosphere. In these discourses, humankind is often analysed as the main unit. Owing to this unit of analysis (extra-humankind), the discourse has increased our understanding of humans in relation to non-humans. The Anthropocene discourses rooted in social sciences and humanities, again, have examined the causes and consequence of the ecological crisis within humankind. By doing so, they have produced valuable knowledge on the contextual particularities of the Anthropocene. On the one hand, these include studies on who within the human species are the main culprits of ecological damage, and on the other hand, how equally the costs are distributed. This unit of analysis (intra-humankind) has led especially to the study of the regional, cultural, and class differences of the Anthropocene.

The social science-based Anthropocene discourses are often seen to be on a crash course with the natural science behind the Anthropocene. Our argument is that the relevance of both of these discourses should be acknowledged so as not to continue the Kuhnian paradigm war (see Kuhn, [1962] 2012). We claim that any further widening of the divide between natural and social sciences would be 
counterproductive to advancing an urgently needed interdisciplinary understanding on how to exit the Anthropocene epoch. Complex problems, such as the ecological crisis, cannot be addressed by a single paradigm or systems level, but require an interdisciplinary approach (Voinov and Farley, 2007; Brandt et al., 2013; Clayton and Radcliffe, 2015).

As the anthropogenic epoch is detrimental to the diversity of life on Earth, we must exit the Anthropocene. But how? The discourses regarding the epoch all have their strengths and weaknesses for this task. For instance, discourses that importantly highlight power imbalances in the biosphere between species also reduce humankind to a single unit, a collective agent. By doing so, they fail to analyse the power differences within humans. The critics of these extra-humankind discourses have conducted important analyses on particularities within humankind (e.g. Malm and Hornborg, 2014; Moore, 2015; Swyngedouw and Ernstson, 2018). They have persuasively claimed that humanity, as a whole, has never been an agent, but it has rather been a small and powerful minority of humans, and a particular economic organisation, which have led 'us' to the Anthropocene.

Instead of making an argument in favour of either natural or social sciences, this article aims to reconcile the tensions about 'the Anthropocene' by reviewing the discourses on the new geological epoch, and distinguishing them from the epoch itself. The contribution is two-fold. Firstly, the study converges the competing Anthropocene discourses by showing their complementarity. Secondly, the study makes a separation between Anthropocene discourses and the epoch - the anthropogenic biophysical processes not captured by or reduced to any talk or text on these processes. It is proposed that the urgently needed exit from the epoch will be supported by collaboration between disciplines and approaches. This convergence in the discourses could pave the way for effective sustainable change.

The article begins by presenting the new geological epoch and discourse about it. We conceptualise the Anthropocene as a contested notion encompassing both an understanding of the Anthropocene as an anthropogenic geological epoch, as well as a view of the Anthropocene as discourses (Section 2). The article proceeds to examining the logic of capital accumulation, as economic organisations based on growth and productivism are identified as one of the main reasons behind the 
Anthropocene epoch (Section 3). Before the concluding remarks, the article discusses the possibilities of exiting the Anthropocene epoch (Section 4).

\section{The Anthropocene}

\subsection{The epoch and discourses about it}

Since its introduction by the atmospheric chemist Paul Crutzen and biologist Eugene Stoermer (2000), the term Anthropocene has become rather popular. In addition to the stratigraphic evidence of a geological epoch (Crutzen and Stoermer, 2000; Steffen et al., 2015a; Waters et al., 2016), the Anthropocene has produced several discourses about it (e.g. Malm and Hornborg, 2014; Di Chiro, 2016). Accordingly, the Anthropocene can signify both the epoch and the discourses about it. By 'epoch', the article refers to the actual (and 'real' in ontological terms) geological changes on Earth, while 'discourses' refer to the linguistic method of human communication (talk, debate, writing, research, etc.) regarding these geological changes and/or how they are understood in a wider socio-economic and ecological frame.

The definition of the Anthropocene is rooted in natural sciences, where it refers to the "geology of mankind". It describes a shift from the previous geological epoch, the Holocene, to a time where humans have become a geological force (Crutzen, 2002: 23). This signifies that the undesired changes in the climate system, as well as the loss of biodiversity, are no longer naturally occurring but are anthropogenic, or human-induced. While the understanding of the Anthropocene as an epoch is persuasive and correct, social scientists and humanists, such as Baskin (2015), Malm and Hornborg (2014), Moore (2015), Lövbrand et al., (2015), Bauer and Ellis (2018) and Swyngedouw and Ernstson (2018) have criticised, not the actual occurrence of the anthropogenic impacts on the biosphere, but rather the proposed name of the epoch and its underlying assumptions. The critique mainly targets how human beings (the anthropos) are understood in the Anthropocene as the locus of the ecological devastation. In other words, the critics question the relevance of considering humankind as the agent that has caused, and continues to cause, the undesired changes in the biosphere. Furthermore, they ponder how aware the natural sciencebased Anthropocene discourses actually are of this implicit assumption, as well as 
its political implications, of humans acting as a collective agent. While it is true that the natural-science led discourse is factual - it has been, and continues to be humans, and not birds or fish that have mainly caused the changes in the biosphere - it is also true that humans have not produced these impacts as a collective agent.

Owing to the observation that historically the positive and negative effects of industrialisation have been very unequally "distributed among social categories within the human species" (Hornborg, 2015: 62), the critics of the extra-humankind discourse consider these questions extremely relevant. More specifically, it is claimed that there is a temporal and spatial separation or disconnect between consumption and where the ecological consequences are most heavily felt (Harvey, 1996). Accordingly, it is claimed that such discourses do little to foster the political action necessary to tackle the ecological destruction taking place beyond a global, flawed technocratic form of governance (see Hamilton, 2013; Hamilton et al., 2015), and the natural science-based definition of the Anthropocene is consequently problematic.

Perhaps the reason why the critics, who consider the nomenclature on the Anthropocene such an important issue - i.e., what to call and how to talk about the epoch - lies in a constructivist idea of language creating reality; at least social reality (see e.g. Malm, 2018). Some critics, on the other hand, argue that the argument is less about the term as such and more about targeting a specific understanding of social processes, power, and modes of organisation that are built on destructive and imperialist relations with the non-humans (e.g. Simpson, 2018). Moreover, the extrahumankind discourse is claimed to be a-historic (Moore, 2015), de-politicised (Clark, 2015; Lövbrand et al., 2015), and de-politicising (Swyngedouw and Ernstson, 2018). Be that as it may, the critique calls for reflection on reasons that have got "us" into this mess, and consequently: what can and should be done to get out of it?

It is of course pertinent to question whether the term 'Anthropocene' is based on a narrow worldview offering only a limited normative guide to action; or even worse, that it may leave the prescription implicit behind the hegemonic understanding of what should be done (Malm and Hornborg, 2014; Hornborg, 2015; Di Chiro, 2016). For instance, under the current dominance of positivist techno-science and 
capitalism, solutions to the problems of the Anthropocene epoch might even justifiably be sought in geoengineering (Clark, 2015; Hamilton, 2013). After all, depending on the underlying ontological and epistemological perspectives, not only are different responses proffered, but different problems are perceived. Hence, a universalising Anthropocene discourse could also be taken as an attempt to put forward or reproduce the techno-scientific worldview. In this light, the Anthropocene resembles a paradigm rather than merely a new geological epoch (Baskin, 2015), and therefore, in defining the Anthropocene, it is important to include other discursive variants.

\subsection{Variations in the Anthropocene discourses}

The start date of the anthropogenic geological epoch was the subject of debate even before the Anthropocene discourses commenced. The birth of the epoch divides the Anthropocene discourse broadly into two other and separate ontological and epistemological camps: the so-called good Anthropocene and the bad Anthropocene (Dalby, 2016; Hamilton, 2016; Kunnas, 2017). According to the advocates of the good Anthropocene discourse, the epoch began as early as 8,000 years ago, when humans started clearing forests and farming (e.g., Ruddiman, 2003). Philosophically, this fits well with the so-called flat ontology (and other borderless metaphysics) that considers industry and technology as inherent parts of nature (e.g. Haraway, 2015; Latour, 2002).

The bad Anthropocene discourse in contrast proclaims that the epoch began with the rapid industrialisation and technologisation of the mid- to late-eighteenth century (e.g. Crutzen and Stoermer, 2000). According to this discourse that considers the epoch as something undesired, there was a point in history when the human species' impact on the ecosystems became globally noticeable (for a debate on the marker, see Lewis and Maslin, 2015). Indeed, the bad Anthropocene association can be challenged from the relational perspective (e.g., Haraway, 2015; Latour, 2002), which asserts that it is impossible to mark a time in history pinpointing the beginning of significant human influence on the Earth, as humans and non-human actors are so tightly interconnected (Davies, 2016). If, however, everything (or alternatively nothing) is considered to be natural, it is difficult to make an argument for sustainable change, as from this perspective, all change is in line with nature (see Malm, 2018). 
What is important for the present enquiry is that while it can be claimed that the bad Anthropocene is too practical and arrogant with its realist ontology and objectivist epistemology, the vision of the good Anthropocene must also incorporate a large dose of technological optimism (and perhaps even hubris) suggesting that humans can and should control the biosphere (see Baskin, 2015; Hamilton, 2013). On this tug-of-war over the beginning of the epoch, Hamilton (2013: 202-203) comments that:

if humans have been a planetary force since civilization emerged $[\ldots]$, then there is nothing fundamentally new about the last couple of centuries of industrialism. It is in the nature of civilized humans to transform the Earth, including by the use of geoengineering, and what is in the nature of the species cannot be resisted. By focusing attention on 'humankind' in general rather than forms of social organization that emerged more recently, the Anthropocene becomes in some sense natural. It is not the product of industrial rapaciousness, an unregulated market, human alienation from nature or excessive faith in technological power; it is merely the result of humans doing what humans are meant to do.

Malm and Hornborg (2014: 65) highlight this as the main paradox of the Anthropocene discourse, since the anthropogenic changes are at one moment denaturalised - relocated from the sphere of natural causes to that of human activities - only to be re-naturalised in the next, when derived from an innate human trait, such as the ability to control fire. It follows that it is not nature as a whole but human nature that is at work here: "The question of fire-use and of the destructiveness of the human species seems a huge one to foist on a tiny lyric, a breach of decorum and scale of a kind endemic to the Anthropocene" (Clark, 2015: 61). This cultural pessimism might be one of the main reasons that many social scientists are not fond of the using the term 'Anthropocene'. Other social scientists, such as Clark (2015), Hamilton et al. (2015), and Heikkurinen (2017), on the other hand, continue to actively use and take part in the Anthropocene discourses by employing the term so as not to lose sight of the actual anthropogenic epoch, even though they clearly share the understanding of the problems associated with the term and discourses.

\subsection{Sociogenics of the Anthropocene}


A consensus within the scientific community is emerging that the severe anthropogenic impacts on the biosphere began to materialise somewhere between 1610 and 1964 (Lewis and Maslin, 2015). Of course, the process started much earlier, making both the bad and good Anthropocene relevant viewpoints. "[T]he mastery of fire by our ancestors provided humankind with a powerful monopolistic tool unavailable to other species, that put us firmly on the long path towards the Anthropocene" (Steffen et al., 2007: 614). This notion, however, does not refute industrial revolution as a significant point in time. That is, it contains within it criticism not only of the economic organisation, but also of human nature. With the use of exosomatic tools, humans have become very distinct from other species (Georgescu-Roegen, 1975) causing Clark (2015: 61) to coin the notion of "the ape of fire playing with fire." Affairs certainly did change in the biosphere when humans learned to master fire and burn non-human objects for their benefit; first wood, later coal, and then oil and gas. As Clark (2015: 60) notes, "fire is an instance of a human tool that has physically altered the very physiology of the species as well as its behaviour".

One issue with this view, however, stems from progress becoming understood and presented as something natural and inevitable; a common journey taken by the entire human species irrespective of differences in geographical regions, cultures, civilisations, or class interests. It goes without saying that humans did not collectively deliberate on the questions of technology, such as whether the species should use fire and tools to further progress. For instance, only a fraction of humanity, even in affluent parts of the world such as Great Britain and Belgium, were able to install steam engines in their factories (Malm, 2013; 2016). The fossil fuel economy, the main form of human organisation that has led us to the new geological epoch, was from the very start based on highly inequitable processes and was unequally distributed among the social classes in the world-system, which in fact can also be seen as a requirement for the existence of modern fossil fuel economies and technologies (Hornborg, 2001; 2016; Malm, 2016).

This means that the anthropogenic changes in the biosphere are also sociogenic, pertaining to a specific social order. That is, the driver of change is not merely humans as a species, but also specific social power relations and structures, and 
forms of economic organisation (Bauer and Ellis, 2018; Di Chiro, 2016; Lövbrand et al., 2015; Malm and Hornborg, 2014; Moore, 2015).

To describe these reasons for social change, Hornborg (2015) and Malm and Hornborg (2014) propose that the new epoch with technology as its main change agent should be called the Technocene. Then again, one could ask do animals not also use tools and technology, and which technologies should mark the beginning of a new epoch: iPods, steam engines, wheels, fire? Another label proposed for the contemporary age is the Plutocene (Ulvila and Wilén, 2017). The concept stems from the Greek word ploutos that refers to wealth, matched with the observation that most of the material consumption, energy use and greenhouse gas emissions can be attributed to the richest segment of humanity (Ulvila and Wilén, 2017). Moore (2014a; 2014b; 2015) has argued for the use of the concept of the Capitalocene (originally coined by Andreas Malm), as it emphasises the current new epoch as the age of capital. In a similar vein, Norgaard $(2013 ; 2014 ; 2015)$ suggests the Econocene as a proper term, due to the almost religious status of the economy and economism in many contemporary societies, and because global market activity "increased 50-fold, or more than 16-fold per capita" during the twentieth century (Norgaard, 2014: 44).

Here again one might ask whether the critique of economic structures delves deeply enough. Is there nothing really pertaining to human nature? Is the undesired development merely an unsuccessful social construction? Replacing the term 'Anthropocene' with a more accurate one might offer a way out of the unfair, universalising blame and responsibility of the past and present ecological damage. But then again, successful exit from the imperfect Anthropocene term will not take "us" away from the anthropogenic epoch. The impacts of humans will remain, no matter what we choose to call them, and it seems that there is no single cause behind the ecological crisis.

Despite the prevailing inaccuracies and contradictions, it is important not to get caught up in the technical details about the exact start date of the epoch, or alternatively in arguments about the meaningfulness of the term 'Anthropocene'. Many of the disputes between the proponents and critics of different Anthropocene 
discourses are due to the different units of analysis, that is, emphasising e.g. intra- or extra-humankind relations (Heikkurinen, 2017).

To advance the understanding of how to exit the epoch, it is certainly worthwhile complementing the natural science discourses with the discourses from social science and humanities. In the next section, the article examines the economics of the Anthropocene. As capitalism roughly co-occurs with the birth of the epoch (Lewis and Maslin, 2015), it is worthwhile having a particular focus on this hegemonic mode of economic organisation.

\section{Economics of the Anthropocene}

\subsection{Capitalism}

Capitalism has historically been a very flexible way of organising the economy and has adapted to various forms of social settings (e.g., Arrighi, 2010; Boltanski and Chiapello, 2005; Moore, 2015). It has also been successful in appropriating opposition and resistance as a form of creative raw material to utilise in re-inventing itself (Crouch, 2004; Negri and Hardt, 2000; Streeck, 2012; 2017), in which discourses about ecology have not been an exception (Böhm et al., 2012; Kenis and Lievens, 2015; Kenis and Mathijs, 2014).

This constant shape-shifting renders the task of outlining a specific definition of capitalism somewhat arduous. Nevertheless, it is clear that the concept of capitalism clearly derives from capital ${ }^{1}$. For Marx ([1867] 1973), capital - referring to accumulated material wealth - is the key element in understanding capitalism. When analysed in a specific historical context, capital acquires a more specific definition. For instance, Wallerstein (2003: 13) explains that capital "is not just the stock of consumable goods, machinery, or authorized claims, or material things in the form of money," and elaborates further as follows:

\footnotetext{
${ }^{1}$ In this article, we conceptualize capitalism mainly through capital, because we perceive that expansive capital accumulation (which is the underlying feature of productivist organization of economies more generally) is the main driver of the different sorts of capitalist organization (liberal, authoritarian, state-led, etc.). In doing so, we do not wish to downplay other signifying features of capitalism, such as commodity production for an external body or wage-labour and class society, but to focus on the one we think is the most significant to the argument put forward (for a more specific definition of capitalism, see e.g. Ruuska, 2018).
} 
[I]n this historical system capital came to be used (invested) in a very special way. It came to be used with the primary objective or intent of self-expansion. In this system, past accumulations were 'capital' only to the extent they were used to accumulate more of the same... It was this relentless and curiously self-regarding goal of the holder of capital, the accumulation of still more capital, and the relations this holder of capital had therefore to establish with other persons in order to achieve this goal, which we denominate as capitalist. (Wallerstein, 2003: 13-14).

In a capitalist society, economic actors (e.g. companies, venture capitalists, investors, states, or other economic organisations) organise activities through the fluid deployment of capital by means of investments made in a variety of surplusmaking operations (Harvey, 2014). For these operations, finance is "crucial to the liquidity and mobility of capital as well as to expansion and spreading costs over time" (Calhoun, 2013: 136). Capitalism can also be conceptualised as a historic formation or structure (Wallerstein, 2003; Mann, 2013), as supported by nation states and state institutions, transnational corporations and various international organisations, political arrangements and military power (Crouch, 2004; Ruuska, 2018; Streeck, 2017) that are characterised by hierarchical and unequally integrated material organisations that are fundamentally all embedded in nature (Moore, 2015).

More importantly, Wallerstein (2003) and Harvey (2014) argue that capital is not just accumulated wealth but also a process in which capital is continuously sent to circulate or is spent in search of more capital by those who attempt to accumulate more capital (see also Harvey, 2016). Following this line of thought, the current article conceptualises capitalism as a particular way to organise economic activities. In such a productivist organisation, expansive capital accumulation processes are hegemonic in providing and shaping the material, social, and intellectual bases for social life (Harvey, 2014). This process does not have an end; it exists only to become more of the same, which is also why the article claims that capitalism is sorely unsuited to helping find a way out of the Anthropocene epoch.

\subsection{Economic growth}

Most ecological problems can be traced back to economic growth (GeorgescuRoegen, 1971; Daly, 2011; IPCC, 2014), an inherent and central feature of capitalism and other productivist forms of economic organization (Boltanski and Chiapello, 
2005; Foster, 2009; Salminen and Vadén, 2015; Ruuska, 2018). The capitalistic economic organisation scales up so that what is true for a single capitalist is also largely true at a more systemic level. Capital accumulation has to continue in an expansive manner or the reproduction of capitalism is threatened. Consequently, as Harvey (2014: 222) states, "capital is always about growth and it necessarily grows at a compound rate", whether it is a single economic actor trying to survive in the market or the capitalist economic organisation as a whole. Similarly, Magdoff and Foster (2011: 42) state that no-growth capitalism neither exists, nor is it desirable, because when capital accumulation ceases, or even slows down, an economic downturn or a systemic crisis ensues, which leads to unemployment, bankruptcies and the incurring of both private and public debt. One of the key reasons for the occurrence of these accumulation crises is a social contract known as return on investment. Graeber (2014: 332) asks, "what is 'interest' but the demand that that money never ceases to grow?" The same is true, Graeber (2014) continues, for investments, which are in principle capital placed in the continual pursuit of profit. Therefore, it is safe to say that in capitalism, economic growth is a necessity, meaning there is a constant pressure to accumulate wealth, make profits, enhance productivity, and invest in the future in order to sustain further accumulation and the viability of capitalist economic organisation.

With regard to the ecological costs of the Anthropocene epoch, which are now crystal clear, Daly (1991) is known for emphasising what he calls the impossibility theorem, that is, the paradox between unlimited economic growth and a finite ecosystem (see also Georgescu-Roegen, 1975). Foster's (2009: 15) work also supports this deep tension between a capitalistic mode of organisation and ecological crisis, as he notes:

Capitalism as a world economy, divided into classes and driven by competition, embodies a logic that accepts no boundaries on its expansion and its exploitation of its environment. The Earth as a planet, in contrast, is by definition limited. This is an absolute contradiction from which there is no earthly escape.

While it is clear that the human-induced geological epoch is not reducible to a single cause but consists of a complex bundle of problems (e.g. Foster et al., 2010, p. 1516), it is nevertheless commonly accepted that most ecological problems can be traced to the growth in economic activities leading to an expansive exploitation of various natural resources (IPCC, 2014; Moore, 2015). Problematically for the 
ongoing and deepening ecological crisis (of which the Anthropocene epoch is a manifestation) the capitalist organisation, due to its nature, generates the need for limitless and indefinite growth, which clearly creates a conflict with the planet and its limited natural resources (Foster, 2009; Hornborg, 2014; Jackson, 2009).

In capitalism, capital accumulation unfolds through the commodification of nature (Polanyi, 1968) and the exploitation of human and non-human labour (Moore, 2015). To be able to reproduce and to accumulate more capital, there needs to be an availability of cheap resources, and inexpensive ways and places to dump waste, but also a way to utilise human capital (Polanyi, 1968; Moore, 2015). The availability of these opportunities does not by itself produce capital as value, but it does create the conditions that make value creation in capitalism possible, through enhancements in productivity. In addition to proper social organisation and the availability of cheap resources and labour, the exponential growth in the amount of labour has been enabled by various technical inventions (Mumford, 1967), extensive utilisation of fossil fuels (Malm, 2016), and more broadly, the modern technoscientific culture (Ellul, [1954] 1976; see also Kerschner and Ehlers, 2016). Particularly from the perspective of ecological sustainability, capital and technology seem to form an unholy alliance. Especially in service of capital, technology destroys natural habitats due to extensive resource extraction (Foster, 2009; Heikkurinen, 2016), but it does so in an accelerating manner. This is because the main aim of economic organisations in capitalism is surplus value creation and expansive capital accumulation in order to secure the continuation of their operations. Economic success is largely gained through investment in technology, as it enhances productivity (see Moore, 2015, p. 100). At its simplest, this means that expansive capital accumulation leads to more and more technology being developed and utilised, which leads to ever more natural resources being exploited (Foster, 2009; Heikkurinen, 2016). This is because technological development brings new investment opportunities and new possibilities to accumulate capital. Also, it is true that capital investments in technology lead to new technologies being developed, which again generate new investment opportunities to accumulate more capital. Thus, technological development and the need for expansive capital accumulation feed each other, and push each other forward. 


\subsection{Economic power and inequality}

The Anthropocene epoch is closely related to economic power inequalities within capitalism. The global economy is hierarchically split into different stages and places at the centre and at the periphery, where nations, nation states, transnational corporations, and various agents of national and transnational capital hold different positions in the international division of labour, and play different roles based on dominance, oppression, and dependence (Foster, 2009; Levy and Egan, 2003). In the Anthropocene, some humans and nation states have become exceedingly affluent at the expense of the rest of the human population (Piketty, 2014), as well as at the cost of non-humans (Jensen, 2006). This exclusive affluence of the few is also an outcome of the exploitation, oppression, and domination of the former colonial countries, which have supported the industrial or post-industrial countries with their supply of cheap raw materials and labour force (Hornborg, 2014).

In the case of climate change, for instance, the benefits and disadvantages derived from capitalist organisation can be seen in the distribution of carbon emissions over time. The Global North, in this case not accounting for per capita intra-country differences, was responsible for $72.7 \%$ of the carbon dioxide emitted between 1850 and 2008, while only hosting $18.8 \%$ of the global population (Malm and Hornborg, 2014; see also Heede, 2014). Furthermore in 2015, the richest $10 \%$ of the global population were responsible for approximately $45 \%$ of $\mathrm{CO}_{2}$ emissions, while the poorest $50 \%$ were responsible for $13 \%$ (Chancel and Piketty, 2015). In the search for alternatives to capitalism, it might also be fruitful to compare socio-economic classes on a global scale, as they neatly illustrate a source of the Anthropocene problem (see Figure 1 and Tables 1 and 2). 


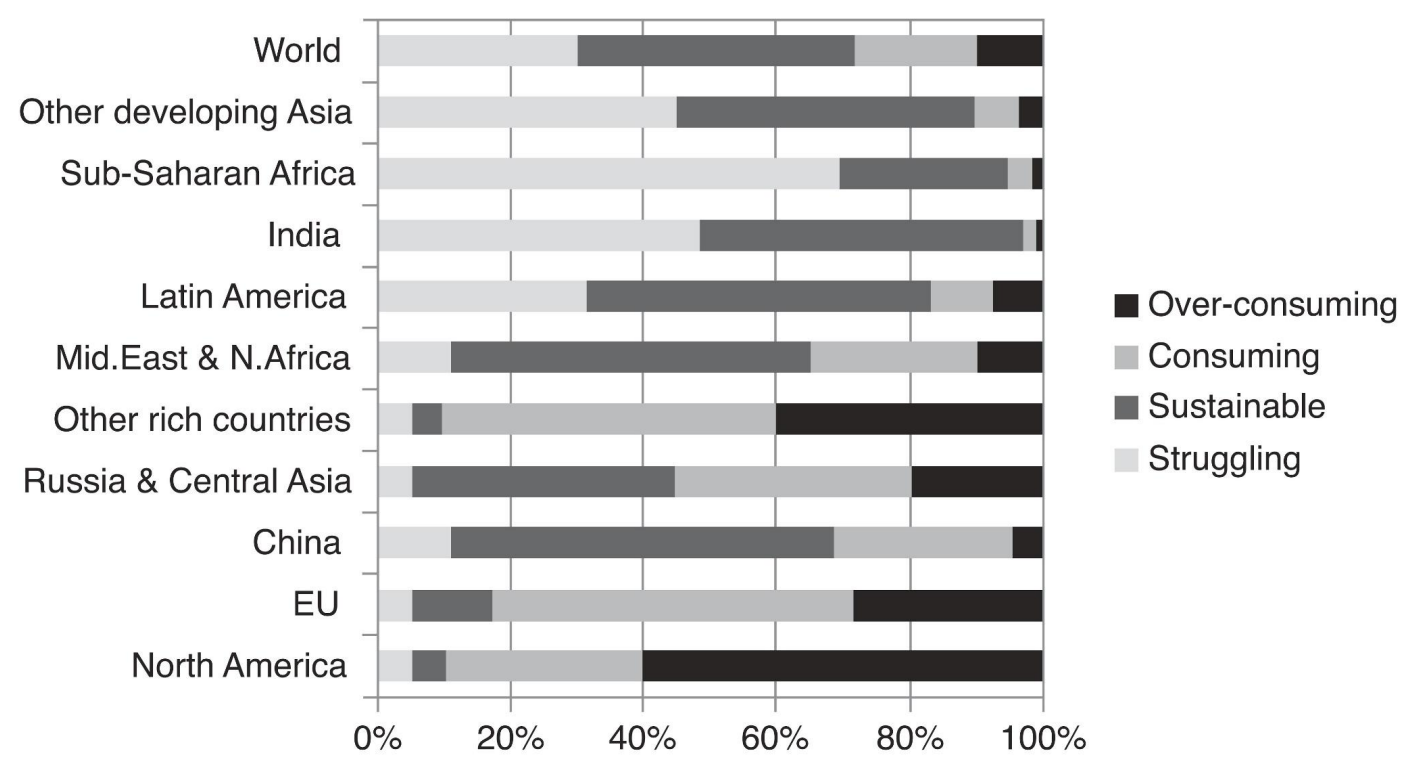

Figure 1 The shares of the four classes globally and across regions in 2013 (Ulvila and Wilén, 2017)

Figure 1 presents four global income-based classes, Table 1 illustrates the conceptual basis for the classes, and Table 2 shows more specifically the locations of the consuming and over-consuming classes and the yearly income thresholds for these classes. The premise of this grouping is that income is strongly related to both the fulfilment of basic needs and the scale of ecological harm (Ulvila and Wilén, 2017). Income can thus function as a useful proxy and indicator of ecological damage. The four global classes identified by Ulvila and Wilén (2017) are: struggling, sustainable, consuming, and over-consuming.

\begin{tabular}{llll}
\hline \hline Income level & Basic needs & Scale of ecol. damage & Name of the class \\
\hline Low & Not met & Small & Struggling \\
Moderate & Met & Moderate & Sustainable \\
High & Met & Significant & Consuming \\
Very high & Met & Very high & Over-consuming \\
\hline
\end{tabular}

Table 1 The conceptual basis for the four income-based classes (Ulvila and Wilén, 2017) 
Accordingly, an effective idea for moving out of the epoch would have a far greater impact when applied to an income-based understanding of the socio-economic alternatives. As Ulvila and Wilén (2017) suggest, empowerment - where the poor would have the right to natural resources on which they depend, the right to have basic needs met through their own efforts whenever possible, and the right to an equal say in matters that affect their lives through the political process - is the only feasible and just option for organising the lives of those living at or below subsistence levels.

Table 2 Number of people belonging to the consuming and over-consuming classes in regions or large countries around the year 2013 (millions) with related rounded income thresholds.

\begin{tabular}{|l|l|l|l|l|}
\hline & \multicolumn{3}{l}{ Consuming class } & \multicolumn{2}{l|}{ Over-consuming class } \\
\hline & $\begin{array}{l}\text { income threshold } \\
(\epsilon)\end{array}$ & $\begin{array}{l}\text { number of } \\
\text { people }(\mathrm{m})\end{array}$ & $\begin{array}{l}\text { income } \\
\text { threshold }(€)\end{array}$ & $\begin{array}{l}\text { number of } \\
\text { people }(\mathrm{m})\end{array}$ \\
\hline North America & 5850 & 105 & 14280 & 211 \\
\hline EU & 6160 & 268 & 13780 & 141 \\
\hline China & 2730 & 370 & 6660 & 59 \\
\hline Russia \& Central Asia & 5900 & 80 & 14610 & 44 \\
\hline Other rich countries & 7080 & 64 & 17280 & 51 \\
\hline Mid.East \& N.Africa & 6510 & 78 & 16660 & 31 \\
\hline Latin America & 10330 & 47 & 23980 & 36 \\
\hline India & 5600 & 25 & 14400 & 13 \\
\hline Sub-Saharan Africa & 5520 & 22 & 11050 & 9 \\
\hline $\begin{array}{l}\text { Other developing Asian } \\
\text { countries }\end{array}$ & 5600 & 68 & 14400 & 34 \\
\hline World & & 1127 & & 629 \\
\hline
\end{tabular}

Source: Ulvila and Wilén, 2017 (data from Chancel and Piketty, 2015)

A significant proportion of the global population lives on a sustainable basis. Therefore, if the growth imperative were to be removed, they could continue their lives with this material standard, in a steady-state fashion (see Daly, 1991). However, for the majority of citizens in the Global North, that is, the over-consuming segment of humanity, a degrowth organisation (see Kallis et al., 2012; Latouche, [2007] 2009) would be necessary to reduce the ecological damage significantly (Ulvila and Wilén, 2017). Proposals addressing over-consumption by the rich could for example include 
establishing a maximum income through high progressive income tax rates or laws limiting the highest salaries in comparison with the lowest ones, for example at the ratio of 5:1 or 10:1 (Ulvila and Wilén, 2017).

Certainly, these economic power imbalances and inequalities at the global level take time to change for a more just and sustainable organisation. This becomes clear when looking at the current situation, where the consuming and over-consuming classes benefit from a continuous ecologically unequal exchange (Hornborg, 2011), while simultaneously functioning as role models for many, something to strive for; become an over-consumer! Indeed, capitalism depends not only on the ever-increasing amount of natural resources turned into raw materials and technologies (Moore, 2015) and flexible and uncertain labour conditions (Crouch, 2004), but also on compliant human subjects as particles of mass consumerism (Streeck, 2012; 2017).

These figures and tables demonstrate again that the Anthropocene epoch is not only driven by humanity as a whole, but especially and particularly by a small group of wealthy organizations and individuals (see also Vitali et al., 2011). As Schumpeter predicted in Capitalism, Socialism and Democracy ([1942] 1950), the capitalist organisation of economies has led to a form of corporatism, where transnational corporations steer and influence public decision-making and possess much of the global wealth (see also Robinson, 2014). This suggests that clearing a path out of the Anthropocene must involve addressing how to dismantle or turn away from the prevailing capitalist economy based on growth and productivism with a focus on the over-consuming classes and societies. This change is not of course limited to capitalism, but includes other productivist organisations geared towards economic growth, as Daly and Cobb (1994: 12-13) remark:

\footnotetext{
Although industrialism grew up historically under capitalist institutions, it has proven to be compatible with socialist institutions as well. The conflict between capitalism and socialism is not about the desirability or possibility of industrialism. That is taken for granted by both sides. The conflict is over which economic system can better produce a growing quantity of goods and services and equitably spread the benefits of the industrial mode of production. Whatever their ideological differences both systems are fully committed to large-scale, factory-style energy and capital-intensive, specialized production units that are hierarchically managed. They also rely heavily on nonrenewable resources and tend to exploit renewable resources and waste absorption capacities at nonsustainable rates.
} 


\section{Discussion}

\subsection{How to exit the epoch?}

The review and analysis conducted in this article suggest that the current organisation of the economy, largely defined by economic growth and productivism, have led us to the Anthropocene epoch. Essentially, this finding signifies that exiting the concurrent destructive epoch must involve abandoning capitalism, but also other forms of productivist organisations. In this sense, Clark raises an important issue (2015: 2-3):

It is not now enough to identify modern capitalism as the exclusive agent of environmental violence. Aside from the fact that socialist systems of government have also had appalling environmental records, the processes culminating in the Anthropocene include events that predate the advent of capitalism, primarily the invention of agriculture, deforestation and the eradication over centuries of large mammals in all continents beyond Africa as humanity expanded across the globe.

It seems therefore that unfortunately, the most prominent historical alternatives to capitalism neither offer easy fixes to the prevailing ecological destruction nor a way out of the Anthropocene. For example, most streams of "Marxism and neo-Marxism do not reject industry and technology, but only their capitalistic organization" (Severino, [1982] 2016: 6). Such anti-capitalism is important, but arguably not sufficient to drive the required transformation of the economy. As Severino remarks ([1982] 2016: 6-7):

The communist revolution simply replaces the capitalistic with a socialistic organization of technology, while both forms of organization share that meaning which reality — which the "thing"-assumes within technology itself. And today it is within this meaning — within the project of the production and destruction of all things - that any attempt to render technological civilization less inhuman must be made. Socialist humanism and ecology do not advocate the abolition of this project - they simply affirm that, if rendered more rational, it would become more efficient and more in keeping with the essential values of the day.

Accordingly, in addition to the need to dismantle the capitalistic and other forms of productivist economic organisations (Heikkurinen et al., 2019), there is a requirement to go beyond the faith in progress and rationalist techno-scientific solutions (Hamilton et al., 2015; Heidegger, [1952-1962] 1977; von Wright, 1978) 
in the Anthropocene discourses. Ultimately, this signifies that those assumptions that place confidence in human skills and capabilities to master the Earth or create a good Anthropocene epoch are questionable (cf. Bannon, 2014; Hamilton, 2013). This discourse is anthropocentric, considering humans as exceptional beings above all other forms of life and the only source of intrinsic value (White, 1967; Næss, [1974] 1989; Purser et al., 1995). As these premises are of limited use in the search for an ecological form of economics and organisation (Gosling and Case, 2013; Ezzamel and Willmott, 2014; Purser et al., 1995; Starik and Rands, 1995; Heikkurinen et al., 2016), the revolution that scholarly work calls for must be complemented by an ethos that reaches beyond anthropocentric discourses (Bannon, 2014; Næss, [1974] 1989; Vetlesen, 2015).

Perhaps paradoxically, the epoch seems to call for a non-anthropocentric discourse to guide the organisation of economies, and also "entails thinking on scales of space and time often considerably greater than usual" (Clark, 2015: 29). As local ecosystems continue to degrade and collapse, temporally they take the whole human civilisation closer to its end point; one micro-collapse at a time. Each species that becomes extinct and each language and the related knowledge systems that disappear constitutes an irreversible collapse to be cared about. The urgency to change the violent conduct of humans (in particular the affluent ones) increases, but simultaneously the rush to transform the economy also fades. That is, as the epoch proceeds, the window of opportunity for human-induced social change also narrows. This signifies that it is always more worthwhile to change the direction now rather than later (Heikkurinen, 2017). In other words, the closer the human species moves to a sudden depopulation, the slimmer the chances of human survival become.

In terms of space, the human modifications in the biosphere continue to set spatial limitations on what can still be done to facilitate an even partial recovery of ecosystems, and hence to begin departing the Anthropocene epoch. The more the local ecosystems and their species are taken over by productivist human organisations - be they capitalist or socialist - the lower the possibility that ecosystems might heal. Every transformation of a non-human-made entity or process into a human-made version beyond the sustainable level is a step nearer to the tipping point (Heikkurinen, 2016; 2017). The state shift theory (Barnosky et al., 2012; Scheffer et al., 2009), for instance, suggests that once critical thresholds are passed, 
ecosystems will undergo unanticipated and irreversible changes into radically altered biotic states, which are unlikely to be habitable for the species living in the Anthropocene, including most or all humans.

The temporal dimension again sets further limitations on what can still be done, or in the case of the Anthropocene epoch, undone. As the critical thresholds for human survival are transgressed, the social change that might emerge is likely to have a limited effect on altering the course of those natural forces already set in motion by those privileged humans in charge of productivist organisations, such as corporations. While non-human processes certainly exhibit extraordinary recovery ability and resilience, much of the anthropogenic damage caused is irreversible. A lost species, for instance, will never return, and there are limits to how much humans can disturb and disrupt the biosphere (Rockström et al., 2009; Whiteman et al., 2013).

Despite the gloomy prospect of diversity loss and habitat destruction, it is both interesting and important to remain open to the idea of the emergence of a new economic organisation. Every act of peace directed towards the world and its inhabitants, whether human or non-human, enhances the quality of life and moves the prospect of extinctions further away toward another place and time. Hence, each action and each inaction contribute to the aspiration to sustain life, but of course as Gorz notes, "survival is not an end in itself" ([1975] 1980: 3-4). The world must be a place that is worth surviving for.

To exit from the Anthropocene epoch, the organisation of the economy in line with the productivist assumption, which assumes that measurable productivity and growth are the desired purpose of human organisation, must be abandoned (see Heikkurinen et al., 2019). Finding a way to exit the Anthropocene epoch would be relatively simple if the problem were only about the wealthiest one percent of individual humans, or only about the recent developments in the Global North. Productivist economics (not limited to capitalism) have already involved most countries. Moreover, it may well be that the will to acquire power - to destroy, create, and control others - runs far deeper in the history of the species (Heikkurinen, 2017). Hence, the withdrawal from contemporary organisations should not be limited to capitalist modes, but should include any form of "growth society based upon the 
development of productive forces" (Latouche, [2007] 2009: 89). The extent of withdrawal should of course depend on the amount of destruction occasioned, which could for instance be measured through changes in household income (Ulvila and Wilén, 2017). Finally, changing the way we discourse about the Anthropocene epoch is of vital importance for effective political action.

\subsection{Which discourses to exit?}

A major problem with most Anthropocene discourses is their inherent anthropocentrism. The natural science-based discourses (often extra-humankind) are not anthropocentric in the same manner as social science discourses are. In many cases, as reviewed above, the latter demonstrates "ontological anthropocentrism", which suggests that the existence of entities in the world is dependent on humans, and for these discourses, it is difficult to accept a real epoch that does not reduce to language and human perception. This is not the kind of anthropocentrism natural sciences demonstrate. These discourses are neither anthropocentric in the sense of "epistemic anthropocentrism, which considers humans the only sources of value (or the only valuers)" or "moral anthropocentrism, which considers humans as the only locus of inherent moral value" (Heikkurinen, 2018: 7). The extra-humankind discourses are anthropocentric owing to their unit of analysis, that is, their focus on humankind as an agent.

This kind of human-centeredness might be termed "agential anthropocentrism" and it can be problematic for exiting the epoch, because it overlooks historical context, class, and power relations and concentrations within the human species (including institutions in terms of rights, duties, privileges and liabilities). Instead, in these discourses the choice is made to investigate humankind as an agent in history. Such a position problematically overlooks the different ecological impacts of different economies.

The "agentially" anthropocentric discourses correctly point out the consequences of humankind on the biosphere. However, in addition to the anthropogenics, the sociogenics of the epoch must be included in the Anthropocene discourse to outline an effective, interdisciplinary response. That is, integrating the extra-humankind and 
intra-humankind discourses will create a better understanding of the causes and consequences of the epoch.

In other words, while the anthropos is claimed to be too broad a discursive category, it is also too narrow a category. Merely focusing on intra-humankind issues neglects the relevance of extra-humankind analysis in both epistemological and axiological senses, as well as in agential terms. As a reality independent of humans is assumed (Bhaskar, 2012; Næss, ([1974] 1989; Vetlesen, 2015), a non-anthropocentric discourse is essential in the search for ecological economics and organisations. Nonhumans should not be excluded from having an ontological status, value in themselves or agential capacities (Heikkurinen et al., 2016). Hence it can be noted that anthropocentrism is problematic in all of its senses: ontological, epistemological, moral, and agential. Therefore, in order to imagine an alternative organisation of the economy, which is capable of leading a way out of the Anthropocene epoch, it is necessary to disengage from the anthropocentric Anthropocene discourses.

The non-anthropocentric Anthropocene discourses could guide our new practices to lead a way out of the Anthropocene. These alternative discourses would be characterised by non-anthropocentrism and non-productivism. Rather than building new discourses on optimistic ideals closely connected to anthropocentrism, such discourse might emerge from cultural pessimism, or from ecological realism (Bonnedahl and Caramujo, 2018; Bonnedahl and Heikkurinen, 2019). By accepting the realities of the ongoing ecological destruction and the violence of the prevalent discourses on technologically mediated progress, a realisation may occur (Heidegger, ([1952-1962] 1977; [1959] 1966). However, "while we no longer believe that progress is a lawlike necessity in any sector of human life, it is still a possibility, which partly depends on our own attitudes and activities" (Niiniluoto, 2011: 108). But what does it take to change the economy and human organisations beyond discourse?

One idea to have found expression in the poetry of many civilizations and religious mythologies is that humanity can only attain wisdom which changes its way of life through suffering and ordeal. These ordeals can affect people in many different ways. In the life of the common people, they can be caused by famine, war, pestilence and great natural disasters. It is possible that we are standing on the brink of an age in which disasters will strike hard and pitilessly. Whether they will make us any the wiser in the 
long term is debatable. On the other hand, these events could affect our conditions of life and, thereby, our way of living it. (von Wright, [1993] 2012: 125).

In the Anthropocene epoch, disasters are already striking hard and many of our human and non-human fellow inhabitants of Earth are suffering accordingly; but such disasters have still not had a significant impact on productivist economies. Because it is not an option to wait for such an impact, it goes without saying that the current structures of power that enable the ecological destruction to continue should be dismantled. However, while the anthropocentric Anthropocene discourse that only focuses on humankind as an agent should be dismissed, it is a moot point whether in this task the term Anthropocene should be used at all.

Clark (2015: 3) considers that "the term, already rather free from the constraints of geological terminology, may remain useful so long as its various but related uses retain a self-critical, even self-destructive force, even marking the term's own equivocality as symptomatic of the kinds of blurring of would-be sharp conceptual, rhetorical, material and disciplinary borders in a newly recognized planetary context." This article proposes that the term may be utilised, as long as the users do not succumb to the merely anthropocentric Anthropocene discourse. After all, despite its problems, the term "represents, for the first time, the demand made upon a species consciously to consider its impact as a totality upon the whole planet, the advent of a kind of new reflexivity as a species" (Clark, 2015: 16). Therefore, perhaps the ecological destruction of the biosphere opens opportunities for ways to understand and organise the economy, and particularly for the consuming and overconsuming classes, to move away from the harm deriving from the productivist and anthropocentric discourses.

\section{Conclusion}

The 'Anthropocene' is a contested term. This article aimed to reconcile the tensions in the scholarly debate by reviewing the Anthropocene discourses, and distinguishing them from the geological epoch. The article demonstrates how both natural and social science-based discourses are relevant in gaining a better understanding of the causes and consequences of the Anthropocene. They provide complementary knowledge on different units of analysis through discourses of 
"extra-humankind" and "intra-humankind". The extra-humankind discourses on the Anthropocene increase our understanding regarding the human place in the biosphere, while the intra-humankind discourses provide a more contextual understanding of the ecological crisis. Instead of continuing the paradigmatic tugof-war, Anthropocene discourses should move towards integration. Moreover, while discourses are key to effective political action, it should be acknowledged that the epoch does not reduce to any linguistic means. We conclude that in order to exit the Anthropocene epoch, anthropocentric discourses on the Anthropocene should be complemented by non-anthropocentric discourses.

\section{Acknowledgements}

The authors wish to express their gratitude to the anonymous reviewers and the editorial team of the journal. Previous versions of this article were presented at the 13th Nordic Environmental Social Science Conference and the 2nd Peaceful Coexistence Colloquium. The authors would also like to thank the organisers and participants of these events. This is project has received funding from the European Union's Horizon 2020 research and innovation programme under the Marie Sklodowska-Curie grant agreement No 707652.

\section{References}

Arrighi G (2010) The Long Twentieth Century: Money, Power and the Origins of Our Times. London: Verso.

Bannon BE (2014) From Mastery to Mystery: A Phenomenological Foundation for an Environmental Ethic. Athens: Ohio University Press.

Barnosky AD, Hadly EA, Bascompte J, Berlow EL, Brown JH, Fortelius M, Getz WM, Harte J, Hastings A, Marquet PA, Martinez ND, Mooers A, Roopnarine P, Vermeij G, Williams JW, Gillespie R, Kitzes J, Marshall C, Matzke N, Mindell DP, Revilla E and Smith AB (2012) Approaching a state-shift in the Earth's biosphere. Nature 486: 52-58.

Bauer AM and Ellis EC (2018) The Anthropocene Divide Obscuring Understanding of Social-Environmental Change. Current Anthropology 59(2): 209-227. 
Bhaskar R, Høyer KG, Næss P (eds) Ecophilosophy in a World of Crisis: Critical realism and the Nordic contributions. London and New York: Routledge.

Böhm S, Misoczky MC and Moog S (2012) Greening Capitalism? A Marxist Critique of Carbon Markets. Organization Studies 33: 1617-1638.

Boltanski L and Chiapello E (2005) The New Spirit of Capitalism. London: Verso.

Bonnedahl, K. and Heikkurinen, P. (2019). Strongly Sustainable Societies: Organizing Human Activities on a Hot and Full Earth. Routledge: London.

Bonnedahl, K. J., \& Caramujo, M. J. (2018). Beyond an absolving role for sustainable development: Assessing consumption as a basis for sustainable societies. Sustainable Development.

Brandt, P., Ernst, A., Gralla, F., Luederitz, C., Lang, D. J., Newig, J., ... \& Von Wehrden, H. (2013). A review of transdisciplinary research in sustainability science. Ecological Economics, 92, 1-15.

Calhoun C (2013) What Threatens Capitalism Now? In: Wallerstein I, Collins R, Mann M, Derluguian G and Calhoun C (eds) Does Capitalism Have a Future? New York: Oxford University Press, pp. 131-162.

Chancel L and Piketty T (2015) Carbon and inequality: from Kyoto to Paris Trends in the global inequality of carbon emissions (1998-2013) \& prospects for an equitable adaptation fund. Available at: http://www.parisschoolofeconomics.eu/en/news/carbon-and-inequalityfrom-kyoto-to-paris-chancel-piketty/ (Accessed 5 December 2015).

Clark T (2015) Ecocriticism on the edge: The Anthropocene as a threshold concept. London and New York: Bloomsbury Publishing.

Clayton, T., \& Radcliffe, N. (2015). Sustainability: a systems approach. Routledge: London

Collins R (2013) The End of Middle-Class Work: No More Escapes. In: Wallerstein I, Collins R, Mann M, Derluguian G and Calhoun C (eds) Does Capitalism Have a Future? New York: Oxford University Press, pp. 37-69.

Crouch C (2004) Post-Democracy. Cambridge: Polity.

Crutzen PJ (2002) Geology of mankind. Nature 415: 23.

Crutzen PJ and Stoermer EF (2000) The Anthropocene. Global Change Newsletter 41: $17-18$.

D'Alisa G, Demaria F, and Kallis G (eds) (2015) Degrowth: A Vocabulary for a New Era. London: Routledge. 
Dalby S (2016) Framing the Anthropocene: The good, the bad and the ugly. The Anthropocene Review, 3(1), 33-51.

Daly HE (1991) Steady-State Economics. Washington, DC: Island Press.

Daly, HE (2011) Growth, debt, and the World Bank. Ecological Economics, 72(15), $5-8$.

Daly, HE, and Cobb JB Jr (1994) For the Common Good: Redirecting the Economy toward Community, the Environment, and a Sustainable Future (2nd edition). Boston: Beacon Press, pp. 12-13).

Davies J (2016) The birth of the Anthropocene. University of California Press: Oakland.

Di Chiro G (2016) Environmental Justice and the Anthropocene Meme. In: Meyer JM, Gabrielson T, Hall C and Schlosberg D (eds) The Oxford Handbook of Environmental Political Theory. Oxford: Oxford University Press, pp. 362384.

Ellul J ([1954] 1976) The Technological Society. New York: Alfred A. Knopf.

Ezzamel M and Willmott H (2014) Registering 'the ethical' in organization theory formation: Towards the disclosure of an 'invisible force'. Organization Studies 35(7): 1013-1039.

Foster JB (2009) Ecological Revolution - Making Peace with the Planet. New York: Monthly Review Press.

Georgescu-Roegen N (1971) The Entropy Law and the Economic Process. Cambridge: Harvard University Press.

Georgescu-Roegen N (1975) Energy and Economic Myths. Southern Economic Journal 41(3): 347-381.

Gordon, RJ (2016) The Rise and Fall of American Growth - The U.S. Standard of Living Since the Civil War. Princeton: Princeton University Press.

Gorz A ([1975] 1980) Ecology as politics. Boston: South End Press.

Gosling J and Case P (2013) Social dreaming and ecocentric ethics: sources of nonrational insight in the face of climate change catastrophe. Organization 20(5): $705-721$.

Graeber D (2014) Debt: The First 5000 Years. London: Melville House.

Graham, M. H., \& Dayton, P. K. (2002). On the evolution of ecological ideas: paradigms and scientific progress. Ecology, 83(6), 1481-1489.

Hamilton C (2013) Earthmasters: the dawn of the age of climate engineering. New Haven: Yale University Press. 
Hamilton C, Bonneuil C and Gemenne F (eds) (2015) The Anthropocene and the Global Environmental Crisis. New York and London: Routledge.

Hamilton, C. (2016). The theodicy of the "Good Anthropocene". Environmental Humanities, 7(1), 233-238.

Haraway D (2015) Anthropocene, capitalocene, plantationocene, chthulucene: Making kin. Environmental Humanities 6(1): 159-165.

Harvey D (1996) Justice, Nature and the Geography of Difference. Oxford: Blackwell.

Harvey D (2011) The Enigma of Capital and the Crises of Capitalism. New York: Oxford University Press.

Harvey D (2014) Seventeen Contradictions and the End of Capitalism. New York: Oxford University Press.

Harvey D (2016) The Ways of the World. New York: Oxford University Press.

Heede R (2014) Tracing anthropogenic carbon dioxide and methane emissions to fossil fuel and cement producers, 1854-2010. Climatic Change 122: 229-241.

Heidegger M ([1952-1962] 1977) The question concerning technology and other essays. Translated by Lovitt W. New York: Garland Publishing.

Heidegger M ([1959] 1966) Discourse on Thinking: a Translation of Gelassenheit. Translated by Anderson JM and Freund EH. New York: Harper \& Row.

Heikkurinen P (2016) Degrowth by means of technology? A treatise for an ethos of releasement. Journal of Cleaner Production 10.1016/j.jclepro.2016.07.070.

Heikkurinen P (ed) (2017) Sustainability and Peaceful Coexistence for the Anthropocene. New York and London: Routledge.

Heikkurinen P, Rinkinen J, Järvensivu T, Wilén K and Ruuska T (2016) Organising in the Anthropocene: an ontological outline for ecocentric theorising. Journal of Cleaner Production 113: 705-714.

Heikkurinen P, Ruuska T, Russell S and Kuokkonen A (2019) Leaving productivism behind: Towards a holistic and processual philosophy of ecological management. Philosophy of Management, https://doi.org/10.1007/s40926019-00109-w.

Hornborg A (2001) The Power of the Machine: Global Inequalities of Economy, Technology, and Environment. Walnut Creek, CA: AltaMira Press.

Hornborg A (2011) Global Ecology and Unequal Exchange: Fetishism in a ZeroSum World. London: Routledge. 
Hornborg A (2014) Ecological Economics, Marxism, and technological progress: Some explorations of the conceptual foundations of theories of ecologically unequal exchange. Ecological Economics 105: 11-18.

Hornborg A (2015) The political ecology of the technocene: uncovering ecologically unequal exchange in the world-system. In: Hamilton $\mathrm{C}$, Bonneuil $\mathrm{C}$ and Gemenne F (eds) The Anthropocene and the Global Environmental Crisis: Rethinking Modernity in a New Epoch. London: Routledge, pp. 57-69.

Hornborg A (2016) Global Magic: Technologies of Appropriation from Ancient Rome to Wall Street. New York: Palgrave Macmillan.

Introna LD (2009) Ethics and the speaking of things. Theory, Culture \& Society 26(4): 25-46.

IPCC (2014) 5th Assessment Report. Climate change 2014: Impacts, Adaption, and Vulnerability. Working Group II. Geneva: Intergovernmental Panel on Climate Change.

Jackson T (2009) Prosperity without Growth: Economics for a Finite Planet. London: Earthscan.

Jensen D (2006) Endgame, vol. 1: The Problem of Civilization. New York: Seven Stories Press.

Kallis G, Kerschner C and Martinez-Alier J (2012) The economics of degrowth. Ecological Economics 84: 172-180.

Kempf H (2008) How the Rich are Destroying the Earth. Devon: Green Books.

Kenis A and Lievens M (2015) The Limits of the Green Economy: From Reinventing Capitalism to Repoliticising the Present. London: Routledge.

Kenis A and Mathijs E (2014) Climate change and post-politics: Repoliticizing the present by imagining the future? Geoforum 52: 148-156.

Kerschner C and Ehlers MH (2016) A framework of attitudes towards technology in theory and practice. Ecological Economics, 126, 139-151.

Kuhn, T. ([1962] 2012). The Structure of Scienfic Revolutions. University of Chicago Press: Chicago.

Kunnas, J. (2017). Storytelling: From the early Anthropocene to the good or the bad Anthropocene. The Anthropocene Review, 4(2), 136-150.

Latouche S ([2007] 2009) Farewell to Growth. Cambridge: Polity Press.

Latour B (2002) Morality and Technology: The End of the Means. Translated by Couze Venn. Theory, Culture \& Society 19(5/6): 247-260. 
Levy DL and Egan D (2003) A Neo-Gramscian Approach to Corporate Political Strategy: Conflict and Accommodation in the Climate Change Negotiations. Journal of Management Studies 40: 803-829.

Levy DL and Spicer A (2013) Contested imaginaries and the cultural political economy of climate change. Organization 20(5): 659-678.

Lewis, Simon L., and Mark A. Maslin. "Defining the anthropocene." Nature 519.7542 (2015): 171.

Lövbrand E, Beck S, Chilvers J, Forsyth T, Hedrén J, Hulme M, Lidskog R and Vasileiadou E (2015) Who speaks for the future of Earth? How critical social science can extend the conversation on the Anthropocene. Global Environmental Change 32: 211-218.

Magdoff F and Foster JB (2011) What Every Environmentalist Needs to Know about Capitalism. New York: Monthly Review Press.

Malm A (2013) The origins of fossil capital: From water to steam in the British cotton industry. Historical Materialism 21: 15-68.

Malm A (2016) Fossil Capital: The Rise of Steam Power and the Roots of Global Warming. New York: Verso.

Malm A (2018) The Progress of This Storm: Nature and Society in a Warming World. London and New York: Verso.

Malm A and Hornborg A (2014) The geology of mankind? A critique of the Anthropocene narrative. The Anthropocene Review 1: 62-69.

Mann M (2013) The End May Be Nigh. In: Wallerstein I, Collins R, Mann M, Derluguian G and Calhoun C (eds) Does Capitalism Have a Future? New York: Oxford University Press.

Marx K ([1867] 1973) Capital: A Critique of Political Economy, Volume 1: The Process of Capitalist Production. Translated by Moore S and Aveling E. New York: International Publishers.

McKibben B (2013) Don't imagine the future-it's already here. Organization 20(5): 745-747.

McKibben B. (1989) The End of Nature. New York: Anchor.

Meadows D, Meadows D, Randers J and Behrens W (1972) The Limits to Growth. New York: New American Library.

Meadows D, Randers J and Meadows D (2005) Limits to Growth: The 30-Year Update. London: Earthscan. 
Moore JW (2007) Ecology and the Rise of Capitalism. Doctoral Dissertation. Berkeley: University of California.

Moore JW (2014a) The Capitalocene, Part I: On the Nature \& Origins of Our

Ecological Crisis. Available at:

http://www.jasonwmoore.com/uploads/The_Capitalocene_Part_I_June_20 14.pdf (Accessed 20 November 2015).

Moore JW (2014b) The Capitalocene, Part II: Abstract Social Nature and the Limits to Capital. Available at: http://www.jasonwmoore.com/uploads/The_Capitalocene__Part_II_June_ 2014.pdf (Accessed 20 November 2015).

Moore JW (2015) Capitalism in the Web of Life: Ecology and the Accumulation of Capital. New York: Verso.

Mumford L (1967) Technics and Human Development: The Myth of the Machine. New York: Harvest/HBJ.

Næss A ([1974] 1989) Ecology, Community and Lifestyle. Traslated by Rothenberg D. Cambridge: Cambridge University Press.

Næss A (1973) The Shallow and the Deep, Long-range Ecology Movement. A Summary. Inquiry 16: 95-100.

Negri A and Hardt M (2000) Empire. Cambridge: Harvard University Press.

Niiniluoto I (2011) Progress by Enlightenment: Fact or Fiction? Temenos 47(1): 87110.

Norgaard RB (2013) The Econocene and the California delta. San Francisco Estuary \& Watershed Science 11(3): 1-5.

Norgaard RB (2014) Escaping Economism, Escaping the Econocene. In: Schneidewind U, Santarius T and Humburg A (eds) Economy of Sufficiency: Essays on wealth in diversity, enjoyable limits and creating commons. Wuppertal: Wuppertal Institute for Climate, Environment and Energy, pp. 44 52.

Norgaard RB (2015) The Church of Economism and Its Discontents. Available at: http://www.greattransition.org/publication/the-church-of-economism-andits-discontents (Accessed 20 March 2016).

Oxfam (2017) An Economy for the 1\%. It's time to build a human economy that benefits everyone, not just the privileged few. Available at: https://www.oxfam.org/sites/www.oxfam.org/files/file_attachments/bpeconomy-for-99-percent-160117-en.pdf (Accessed 30 January 2017). 
Pataki G (2009) Ecological modernization as a paradigm of corporate sustainability. Sustainable Development 17(2): 82-91.

Piketty T (2014) Capital in the Twenty-First Century. Cambridge, MA: Harvard University Press.

Purser RE, Park C and Montuori A (1995) Limits to anthropocentrism: Toward an ecocentric organization paradigm? Academy of Management Review 20(4): $1053-1089$.

Rickards LA (2015) Metaphor and the Anthropocene: Presenting Humans as a Geological Force. Geographical Research 53(3): 280-287.

Robinson WI (2014) Global Capitalism and the Crisis of Humanity. New York: Cambridge University Press.

Rockström J, Steffen W, Noone K, Persson Å, Stuart Chapin F, Lambin E, Lenton TM, Scheffer M, Folke C, Schellnhuber HJ, Nykvist B, De Wit CA, Hughes T, Van der Leeuw S, Rodhe H, Sörlin S, Snyder PK, Costanza R, Svedin U, Falkenmark M, Karlberg L, Corell RW, Fabry VH, Hansen J, Walker B, Liverman D, Richardson K, Crutzen P and Foley J (2009) Planetary Boundaries: Exploring the Safe Operating Space for Humanity. Ecology and Society 14(2): 32.

Ruddiman W (2003) The anthropogenic greenhouse era began thousands of years ago. Climatic Change 61: 261-293.

Ruuska T (2018) Reproduction Revisited: Capitalism, Higher Education and Ecological Crisis. MayFly Books, available at mayflybooks.org.

Scheffer M, Bascompte J, Brock WA, Brovkin V, Carpenter SR, Dakos V, Held H, van Nes EH, Rietkerk M and Sugihara G (2009) Early-warning signals for critical transitions. Nature 461(7260): 53-59.

Schumpeter JA ([1942] 1950) Capitalism, Socialism and Democracy. New York: Harper.

Severino E ([1982] 2016) The Essence of Nihilism. Translated by Donis G. London and New York: Verso.

Simpson M (2018) The Anthropocene as colonial discourse. Environment and Planning D: Society and Space. DOI: 10.1177/0263775818764679

Starik M and Rands GP (1995) Weaving an integrated web: Multilevel and multisystem perspectives of ecologically sustainable organizations. Academy of Management Review 20(4): 908-935. 
Steffen W, Crutzen PJ and McNeill JR (2007) The Anthropocene: Are humans now overwhelming the great forces of nature? Ambio: A Journal of the Human Environment 36(8): 614-621.

Steffen W, Richardson K, Rockström J, Cornell SE, Fetzer I, Bennett EM, Biggs R, Carpenter SR, de Vries W, de Wit CA, Folke C, Gerten D, Heinke J, Mace GM, Persson LM, Ramanathan V, Reyers B and Sörlin S. (2015a) Planetary boundaries: Guiding human development on a changing planet. Science 347: 1259855.

Streeck W (2012) Citizens as Customers: Considerations on the New Politics of Consumption. New Left Review, 76, 27-47.

Streeck W (2017) How Will Capitalism End? Essays on a Failing System. London and New York: Verso.

Swyngedouw E (2013) Apocalypse now! Fear and doomsday pleasures. Capitalism Nature Socialism 24(1): 9-18.

Swyngedouw E (2015) Foreword: Apocalypse now? From the marketisation to the politicisation of the environment. In: Kenis A and Lievens M (eds) The limits of the green economy: from re-inventing capitalism to re-politicising the present. London: Routledge, pp. ix-xv.

Swyngedouw E and E. Ernstson E (2018) Interrupting the anthropo-obScene: Immuno-biopolitics and depoliticizing ontologies in the anthropocene. Theory, Culture and Society. pp. 1-28.

Tainter JA (2015) The Collapse of Complex Societies. Cambridge: Cambridge University Press.

Taylor, C (2007). A Secular Age. Cambridge: Harvard University Press

Ulvila M and Wilen K (2017) Engaging with the Plutocene: moving towards degrowth and postcapitalist futures. In: Heikkurinen, P (ed) Sustainability and Peaceful Coexistence for the Anthropocene. New York and London: Routledge.

Vetlesen AJ (2015) The Denial of Nature: Environmental Philosophy in the Era of Global Capitalism. Oxon and New York: Routledge.

Vitali S, Glattfielder J and Battison S (2011) The Network of Global Corporate Control. PLoS ONE 6(10): e25995.

Voinov, A., \& Farley, J. (2007). Reconciling sustainability, systems theory and discounting. Ecological Economics, 63(1), 104-113. 
von Wright GH ([1993] 2012) A Provocative Pessimism: A postscript on the scientific worldview and global order. In: Bhaskar R, Høyer KG and Næss P (eds) Ecophilosophy in a World of Crisis: Critical realism and the Nordic contributions. London and New York: Routledge, pp. 113-125.

von Wright GH (1978) Humanismen Som Livshållning [Humanism as an Attitude to Life]. Stockholm: Månpocket.

Wallerstein I (2003) Historical Capitalism and Capitalist Civilization. London: Verso.

Wallerstein I (2013) Structural crisis, or why capitalists may no longer find capitalism rewarding. In: Wallerstein I, Collins R, Mann M, Derluguian G and Calhoun C (eds) Does Capitalism Have a Future? New York: Oxford University Press, pp. 9-36.

Waters CN, Zalasiewicz J, Summerhayes C, Barnosky AD, Poirier C, Gałuszka A, Cearreta A, Edgeworth M, Ellis E, Ellis M, Jeandel C, Leinfelder R, McNeill JR, Richer D, Steffen W, Syvitski J, Vidas D, Wagreich M, Williams M, An Z, Grinevald J, Odada E, Oreskes N and Wolfe AP (2016) The Anthropocene is functionally and stratigraphically distinct from the Holocene. Science 351(6269): aad2622-1-10.

White LT Jr (1967) The Historical Roots of Our Ecologic Crisis. Science 55(3767): 1203-1207.

Whiteman G, Walker B and Perego P (2013) Planetary boundaries: Ecological foundations for corporate sustainability. Journal of Management Studies 50(2): 307-336.

Wittneben BBF, Okereke C, Banerjee SB and Levy DL (2012) Climate Change and the Emergence of New Organizational Landscapes. Organization Studies 33(11): 1431-1450. 